\title{
MODIFIKASI TEPUNG LABU KUNING (Cucurbita Moschata) MENGGUNAKAN METODE Heat Moisture Treatment (HMT) DENGAN VARIASI SUHU DAN LAMA PENGERINGAN
}

\author{
Siti Sarifah*, Indah Riwayati, Farikha Maharani \\ Jurusan Teknik Kimia, Fakultas Teknik, Universitas Wahid Hasyim \\ Jl.Menoreh Tengah X/22, Sampangan, Semarang 50236 \\ *Email : sitisyarifa969@gmail.com
}

\begin{abstract}
Abstrak
Kebutuhan tepung terigu yang semakin meningkat, menyebabkan nilai impor tepung terigu juga meningkat sehingga perlu adanya upaya untuk mengurangi impor tepung terigu yaitu dengan memanfaatkan produk lokal seperti labu kuning. Tepung labu kuning masih memiliki kekurangan yakni mempunyai sifat menggumpal, kurang dapat mengembang dan sedikit mengikat air. Sehingga diperlukan modifikasi terhadap karakteristik dari tepung tersebut. Salah satu metode yang digunakan untuk modifikasi tepung labu kuning yaitu Heat Moisture Treatment (HMT). Tujuan dari penelitian ini adalah untuk mengetahui pengaruh HMT terhadap karakteristik swelling power dan solubility tepung labu kuning. Variabel yang digunakan dalam penelitian ini yakni suhu $\left(80,100\right.$ dan $\left.120^{\circ} \mathrm{C}\right)$ dan lama pengeringan $(1,2,3,4$ dan 5 jam). Penelitian ini terdiri dari dua tahap yaitu pembuatan tepung labu kuning dan modifikasi tepung labu kuning menggunakan HMT. Kemudian dilakukan analisa swelling power, solubility dan analisa proksimat. Hasil terbaik pada penelitian ini terdapat pada suhu $100^{\circ} \mathrm{C}$ dengan nilai swelling power $3,789(\mathrm{~g} / \mathrm{g})$ dan solubility $61 \%$. Kenaikan suhu dan lama pengeringan akan mempengaruhi swelling power, solubility, kadar air, kadar abu, karbohidrat, protein, lemak dan serat kasar.
\end{abstract}

Kata Kunci : Labu Kuning, Tepung Modifikasi, Heat Moisture Treatment

\section{PENDAHULUAN}

Tepung terigu merupakan salah satu bahan pangan yang kebutuhannya dari tahun ke tahun semakin meningkat. Berdasarkan Data Badan Pusat Statistik, tercatat impor tepung terigu pada tahun 2014 mencapai 20.198 ton atau US\$ 8,1 juta (Jefriando, 2014).

Salah satu upaya untuk mengurangi impor tepung terigu di Indonesia, dapat dilakukan dengan mengembangkan produk lokal. Pengembangan produk lokal telah dilakukan oleh Sudarman (2017) menggunakan tepung labu kuning (Cucurbita Moschata Duch) sebagai bahan dasar pembuatan cookies.

Labu kuning dapat diolah menjadi tepung. Namun, tepung labu kuning tersebut masih memiliki kelemahan yaitu mempunyai sifat menggumpal, kurang dapat mengembang dan sedikit mengikat air. Upaya untuk mengatasi kelemahan tepung tersebut dengan cara dimodifikasi. Modifikasi tepung bertujuan untuk menghasilkan sifat yang lebih baik dari sifat sebelumnya (Honestin, 2007). Salah satu teknik modifikasi tepung labu kuning yang bisa dipakai adalah Heat Moisture Treatment (HMT).

Heat Moisture Treatment (HMT) merupakan metode modifikasi tepung secara fisik dengan cara memberikan perlakuan panas pada suhu gelatinisasi $\left(80-120^{\circ} \mathrm{C}\right)$ dengan kondisi kadar air terbatas atau dibawah 35\% (Collado dkk., 2001). Berdasarkan pada penelitian yang dilakukan oleh Fetriyuna dkk., (2016) disimpulkan bahwa lama modifikasi HMT memberikan perubahan yang beragam terhadap sifat fungsional pati Talas Banten termodifikasi HMT. Pati Talas Banten mengalami penurunan nilai swelling power dan peningkatan solubility.

Tujuan dari penelitian ini adalah untuk mengetahui pengaruh suhu dan lama pengeringan pada modifikasi HMT terhadap karakteristik tepung labu kuning. Oleh karena itu diperlukan penelitian untuk mengetahui pengaruh kedua variabel terhadap karakteristik tepung labu kuning.

\section{METODOLOGI \\ BAHAN PENELITIAN}

Bahan yang digunakan dalam penelitian ini adalah Labu Kuning dan Aquades.

\section{PERALATAN}

Alat yang digunakan dalam penelitian ini meliputi Pisau, Baskom, Loyang, Tray dryer, 
Ayakan 100 mesh, Alumunium Foil, Blender, Refrigerator, Oven, Waterbath, Centrifuge.

\section{PROSEDUR PENELITIAN}

Labu kuning dikupas kulitnya dan dilakukan pencucian. Kemudian diiris menjadi lembaran-lembaran kecil. Irisan labu kuning direndam selama kurang lebih 5 menit. Selanjutnya dilakukan proses pengeringan menggunakan tray dryer. Labu kuning yang telah kering, kemudian dilakukan penggilingan dan pengayakan menggunakan ayakan 100 mesh.

\section{MODIFIKASI HMT}

1. Pengaturan Kadar Air

Pengaturan kadar air dapat dilakukan dengan penambahan aquades hingga mencapai kadar air yang telah ditentukan, dengan cara penyemprotan dan pengadukan secara manual bertujuan untuk penyeragaman kadar air pada proses Heat Moisture Treatment (HMT). Jumlah aquades yang ditambahkan dihitung menggunakan prinsip kesetimbangan massa. Menurut Adebowale dkk., (2005) rumus kesetimbangan massa yang dapat digunakan adalah sebagai berikut :

$\left(100 \%-\mathrm{KA}_{1}\right) \times \mathrm{BP}_{1}=\left(100 \%-\mathrm{KA}_{2}\right) \times \mathrm{BP}_{2}$

$\mathrm{KA}_{1}=$ Kadar air kondisi awal (\%bb)

$\mathrm{KA}_{2}=$ Kadar air tepung yang diinginkan $(\% \mathrm{bb})$

$\mathrm{BP}_{1}=$ Bobot tepung pada kondisi awal

$\mathrm{BP}_{2}=$ Bobot tepung setelah mencapai $\mathrm{KA}_{1}$

2. Penyeragaman Kadar Air dalam refrigerator

Tepung dibungkus dalam alumunium foil kemudian ditempatkan dalam loyang. Tepung didinginkan dalam refrigerator pada suhu $4-5^{\circ} \mathrm{C}$ selama 24 jam untuk penyeragaman kadar air.

3. Pemanasan

Tepung dikemas dengan alumunium foil tertutup rapat bertujuan untuk menjaga kadar air agar tetap pada kondisi yang diinginkan. Pemanasan dilakukan pada suhu dan waktu yang telah ditetapkan sesuai dengan perlakuan untuk proses modifikasi Heat Moisture Treatment (HMT). Pemanasan dilakukan dengan menggunakan oven.

4. Pengeringan

Tepung yang telah diberi perlakuan pemanasan selanjutnya dibuka untuk dikeringkan dalam oven pada suhu $50^{\circ} \mathrm{C}$ selama 4 jam.

5. Penggilingan

Tepung yang telah dikeringkan selanjutnya digiling untuk memperkecil ukuran dan memudahkan proses pengayakan sehingga didapatkan tepung dengan ukuran yang seragam. Proses penggilingan dilakukan dengan menggunakan blender.

6. Pengayakan

Tepung yang telah digiling kemudian diayak dengan menggunakan ayakan 100 mesh.

\section{Pengujian swelling power dan solubility}

0,1 gram tepung dicampur $10 \mathrm{ml}$ aquades dalam tabung sentrifuse $45 \mathrm{ml}$ dan diaduk. Kemudian diletakkan pada waterbath dengan suhu $85^{\circ} \mathrm{C}$ selama 30 menit dengan pengadukan kontinyu selama 10 detik setelah 5,15 dan 25 menit. Sampel didinginkan pada suhu ruang lalu di sentrifugasi dengan kecepatan $2000 \mathrm{rpm}$ selama 30 menit, supernatan dan residu dipisahkan. Supernatan diletakkan dalam cawan porselen, kemudian di oven pada suhu $105^{\circ} \mathrm{C}$. Residu di dalam tabung ditimbang sampai berat konstan

\section{HASIL DAN PEMBAHASAN \\ Pengaruh suhu dan lama pengeringan terhadap swelling power}

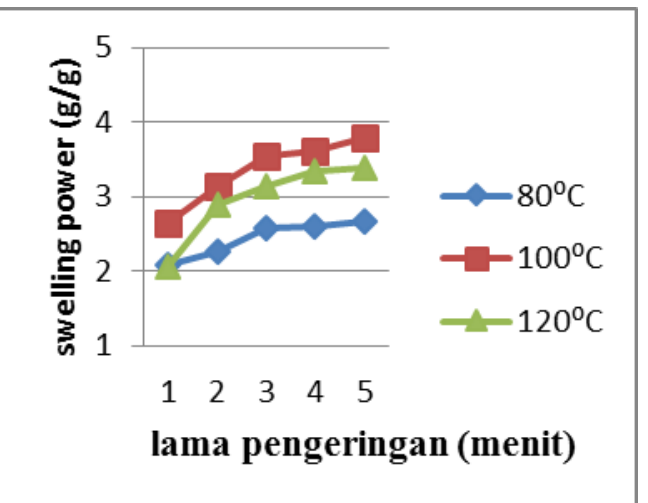

\section{Gambar 1. Hubungan pengaruh suhu dan lama pengeringan terhadap swelling power}

Gambar 1 menunjukkan hasil swelling power tertinggi diperoleh pada suhu $100^{\circ} \mathrm{C}$ dengan lama pengeringan $5 \mathrm{jam}$, hal ini dikarenakan pemanasan pada tepung labu kuning modifikasi HMT akan mengakibatkan perubahan struktur molekul amilopektin, yang berupa penambahn panjang rantai karbon (Setiyoko dkk., 2018). Wang dkk., (2006) menyatakan bahwa swelling power dapat dipengaruhi oleh beberapa faktor yakni perbandingan amilosa-amilopektin, panjang rantai dan distribusi berat molekul. Semakin besar nilai swelling power maka kemampuan mengembang juga akan semakin besar. 
Semakin tinggi suhu pemanasan, maka semakin banyak terbentuk kristalin baru yang dapat meningkatkan stabilitas granula dan mengurangi kemampuan pembengkakan granula.

\section{Pengaruh suhu dan lama pengeringan terhadap solubility}

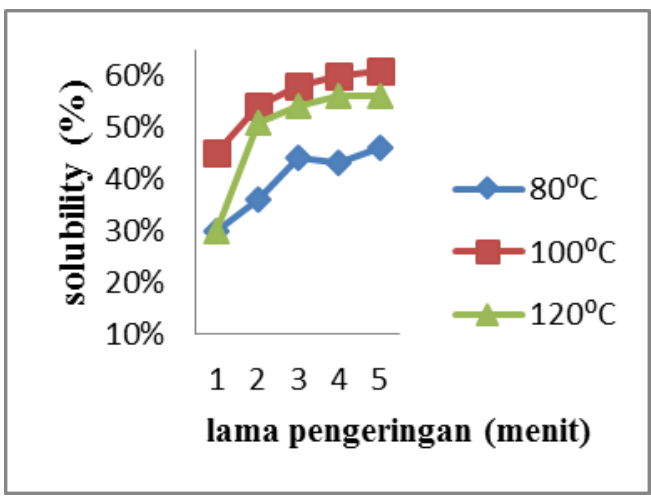

Gambar 2. Hubungan pengaruh suhu dan lama pengeringan terhadap solubility

Berdasarkan gambar 2 diatas dapat disimpulkan bahwa semakin tinggi suhu operasi maka nilai solubility semakin meningkat. Hal tersebut dikarenakan terjadinya starch damage pada saat penggilingan tepung labu kuning. Semakin tinggi starch damage menyebabkan banyak daerah kristalin berubah menjadi daerah amorf sehingga menurunkan kekuatan assosiasi granula (Suksomboon dan Naivikul. 2005). Semakin tinggi suhu, maka semakin banyak pula amilosa yang keluar dari granula pati sehingga nilai solubility atau kelarutan tepung labu kuning juga semakin tinggi.

\section{Analisa proksimat}

Hasil analisa proksimat tepung labu kuning dengan modifikasi HMT pada penelitian ini dibandingkan dengan tepung labu kuning tanpa modifikasi dapat dilihat pada Tabel 1.

Tabel 1. Uji proksimat Tepung labu kuning

\begin{tabular}{ccc}
\hline $\begin{array}{c}\text { Jenis } \\
\text { Analisa }\end{array}$ & $\begin{array}{c}\text { Tepung Labu } \\
\text { Kuning } \\
\text { Modifikasi HMT }\end{array}$ & $\begin{array}{c}\text { Tepung Labu } \\
\text { Kuning } \\
\text { (Non- } \\
\text { Modifikasi) }\end{array}$ \\
\hline Air & 7,067 & 11,14 \\
Abu & 30,366 & 5,89 \\
Karbohidrat & 15,368 & 1,27 \\
Lemak & 0,080 & 1,34 \\
Protein & 4,271 & 3,74 \\
Serat Kasar & 32,308 & 73,38 \\
\hline
\end{tabular}

Uji proksimat tepung labu kuning meliputi kadar air, kadar abu, kadar protein, kadar lemak, kadar serat kasar dan kadar karbohidrat. Dari tabel tersebut, diperoleh nilai kadar air sebesar 7,607 (\%bb). Kadar air sangat dipengaruhi oleh cara penyimpanan atau lama waktu dari pemanenan sampai bahan diolah menjadi suatu produk yang dihasilkan (Lopulalan dkk., 2008). Kadar labu kuning yang dihasilkan memenuhi syarat mutu kadar air tepung labu kuning yang ditetapkan oleh Badan Standarisasi Nasional dalam SNI 3751:2009 yaitu maksimal 14,5\%. Semakin tinggi kadar air dalam suatu bahan pangan, daya simpan serta kualitas bahan pangan juga akan semakin rendah (Arpah,1993).

Hasil analisa kadar lemak tepung labu kuning adalah 0,080 (\%bb). Kadar lemak bukan merupakan salah satu syarat mutu yang ditetapkan dalam standar SNI. Namun, kadar lemak terkait dengan proses gelatinisasi. Hal ini disebabkan karena lemak dapat membuat kompleks dengan amilosa sehingga amilosa tidak keluar dari granula pati. Dengan mengetahui kadar lemak dalam suatu bahan, maka akan memudahkan untuk menentukan tujuan pembuatan suatu produk (Riyani dkk., 2007). Dari hasil analisa tersebut kadar lemak tepung labu kuning lebih rendah sehingga dapat digunakan untuk diet rendah lemak.

Karbohidrat merupakan komponen utama bahan pangan yang memiliki sifat fungsional dalam proses pengolahan. Berdasarkan hasil analisis, nilai kadar karbohidrat tepung labu kuning sebesar 15,368 (\%bb). Beberapa faktor yang dapat menyebabkan perbedaan kandungan karbohidrat adalah penggunaan suhu yang terlampau tinggi pada saat proses pengolahan, interaksi antara pati dengan komponen non pati dan jumlah pati resisten yang terdapat dalam pati (Andarwulan, 2008).

Serat Kasar adalah bagian dari pangan yang tidak dapat dihidrolisis oleh enzin-enzim pencernaan manusia. Berdasarkan hasil analisis, nilai kadar serat kasar tepung labu kuning

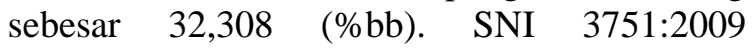
mencantumkan maksimum kandungan serat kasar tepung adalah 1,5 (\%bb). Hal ini berarti kandungan serat pangan yang tinggi bermanfaat untuk kesehatan, namun dari segi kualitas fisik berpengaruh terhadap tekstur atau tingkat kehalusan tepung (Suarni,2009).

Hasil analisis nilai kadar abu tepung labu kuning sebesar 30,366\%. Nilai ini berbeda jauh dengan hasil penelitian sebelumnya yaitu 
4,45\% pada tepung labu kuning yang tidak dimodifikasi. Kadar abu yang tinggi pada bahan tepung kurang disukai karena cenderung memberi warna gelap pada produknya. Perbedaan kadar abu dapat dikarenakan perbedaan varietas labu kuning yang dihasilkan.

Kadar protein merupakan salah satu syarat mutu tepung labu kuning. Hasil analisis kadar protein tepung labu kuning sebesar 4,271 (\%bb) dimana hasil pengujian kadar protein ini tidak memenuhi persyaratan mutu SNI 3751:2009 yaitu minimal $7,0 \%$.

\section{KESIMPULAN DAN SARAN Kesimpulan}

Berdasarkan hasil penelitian, dapat disimpulkan bahwa pembuatan tepung labu kuning dengan modifikasi Heat Moisture Treatment dimulai dari pembuatan tepung labu kuning, pengaturan kadar air, penyeragaman kadar air dalam refrigerator, pemanasan, pengeringan, penggilingan dan pengayakan. Adanya perbedaan suhu dan lama pengeringan dapat mempengaruhi karakteristik tepung labu kuning, yakni nilai swelling power, solubility dan analisa proksimat.

\section{Saran}

Berdasarkan penelitian ini diharapkan adanya pengujian lanjutan, seperti uji amilosa dan amilopektin pada modifikasi HMT tepung labu kuning ketika diaplikasikan ke dalam pembuatan produk.

\section{DAFTAR PUSTAKA}

Adebowale, K.O., Olu-owolabi, B.I., Olayinka,O.O., Olayide, S. 2005. Effect of Heat Moisture Treatment and Annealing on physicochemical properties of red sorghum starch, 4(9), 928-933

Andarwulan, N., 2008. Nilai kalori pangan sumber karbohidrat, Food Review Indonesia, Hal 17-22

Arpah, M. 1993. Pengawasan Mutu Pangan, Tarsito, Bandung.

Collado L.S., Mabesa L.B., Oates C.G.,Corke H. 2001. Bihon Type Noodles from Heat Moisture Treated Sweet Potato Starch. Journal of food science 66:604-609

Fetriyuna, Marsetio, dan Pratiwi RL. 2016. Pengaruh lama modifikasi Heat Moisture Treatment (HMT) terhadap sifat fungsional dan sifat Amilografi Pati talas Banten (Xanthosoma Undipes K. Koch). Jurnal Penelitian Pangan Vol 1.1.
Honestin, 2007. Karakterisasi sifat fisikokimia tepung ubi jalar (lpomoea Batatas). Departemen Ilmu dan Teknologi Pangan. Institut Pertanian Bogor

Jefriando,M. 2014. impor tepung terigu dan mentega meroket. https://finance.detik.com/read.

://finance.detik.com/read/2014/06/03/092 442/2597982/4/impor-tepung-terigu-danmentega-meroket. 17 Juni 2019

Lopulalan, CGC, Sugiyono, Haryanto B. 2008. Kajian Formulasi biskuit jagung dalam rangka substitusi tepung terigu. Jurnal Teknologi Industri Pangan $20: 32-40$.

Riyani, N.A, Sunarti, T.C, Permatasari, N. 2007. Characteristics of sux Indonesia copin grains flours. International Symposium Agricultural Engineering, Bogor, Indonesia.

Setiyoko, A., dan Agus 2018. Karakterisasi Heat Moisture Treatment tepung terigu dan pengaruhnya terhadap kualitas mie basah, Universitas Mercu Buana, Yogyakarta.

Suarni. 2009. Prospek pemanfaatan tepung jagung untuk kue kering (cookies). Jurnal litbang pertanian 28(2) : 63-71.

Sudarman M. 2017. Pemanfaatan labu kuning (Cucurbita Moschata Duch) sebagai bahan dasar pembuatan cookies. Fakultas Teknik Univrsitas Negeri Makasar

Suksomboon A dan Naivikul O. 2005. Effect of dry and wet milling processes on chemical, physicochemical properties and starch molecular structures of rice starches. Kasesart J(Natscr) 40:125-134

Wang. W., Lai.V.,Chang, K., and Ho,H. 2006. Effect of amylopectin structure on the gelatinization and pasting properties of selected yam (Diascorea spp) starches, 58:572-579 